\title{
Haitallinen johtamisviestintä
}

\author{
- Kiusaaminen johtajan ja johdettavan vuorovaikutussuhteessa
}

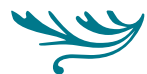

Työpaikkakiusaamista on tutkittu Suomessa jo muutaman vuosikymmenen

ajan, mutta kiusaamisen erityispiirteitä nimenomaan johtajan ja alaisen vuorovaikutussuhteessa on tarkasteltu vain vähän. Lähestymme katsauksessa

kiusaamista tässä erityisessä vuorovaikutussuhteessa ja esittelemme haitallisen johtamisviestinnän käsitteen. Haitallinen johtamisviestintä on yksi kiusaamisen muoto ja ilmenee epätarkoituksenmukaisena vuorovaikutuksena johtajan ja johdettavan vuorovaikutussuhteessa.
\end{abstract}

TYÖPAIKAN MYÖNTEISET vuorovaikutussuhteet ovat keskeisessä asemassa henkilöstön hyvinvoinnin rakentumisessa ja säilymisessä. Työtoverisuhteissa esiintyy kuitenkin myös ristiriitoja, jotka voivat pitkittyessään laajentua vaikeasti ratkaistaviksi kiusaamisprosesseiksi. Koettu kiusaaminen tai tulehtuneet välit työtovereihin voivat johtaa työntekijän kuormittumiseen, uupumiseen ja tehottomuuteen. Työpaikan ristiriitatilanteet voivat lisätä koko työyhteisön pahoinvointia.

Työyhteisön vuorovaikutussuhteiden ongelmatilanteissa korostuu erityisesti esimiehen rooli ja vastuu. Kun työpaikalla koetaan kiusaamista, on johtaja aina tavalla tai toisella prosessin keskeinen osapuoli. Hän voi myös olla osallisena useassa roolissa samanaikaisesti. Ensinnäkin johtaja on asemansa puolesta työnantajan edustajana velvollinen puuttumaan häirintään ja epäasialliseen kohteluun työpaikallla ja ryhtymään tarvittaviin toimenpiteisiin epäkoh- dan poistamiseksi (Työturvallisuuslaki 738/2002, 285). Esimiehen vastuulla on puuttua työntekijöiden välisiin ristiriitatilanteisiin ja työpaikalla havaittavaan epäasialliseen viestintään, hallita ja ratkaista konflikteja ja luoda omalla viestinnällään turvallista työskentelyilmapiiriä, jossa työntekijät voivat olla toistensa kanssa vuorovaikutuksessa avoimesti ja toisiinsa luottaen. Toisin sanoen johtajan viestintäfunktioihin kuuluu tukea työntekijöiden keskinäistä vuorovaikutusta. (Rouhiainen-Neunhäuserer 2009.)

Toiseksi johtajalla on keskeinen asema työpaikkakiusaamisen ennaltaehkäisemisessä. Pelkät työolosuhteiden epäkohdat yksin eivät selitä, mistä työpaikkakiusaaminen johtuu. Kiusaamista kuitenkin koetaan enemmän niillä suomalaisilla työpaikoilla, joissa esimies ei käsittele työhön liittyviä ongelmia tai muita työhön liittyviä asioita riittävän avoimesti ja joissa muutenkin koetaan esiintyvän työnjakoon ja työjärjestelyihin liittyviä ongelmia (Lehto \& Su- 
tela 2008). Kolmanneksi johtaja voi itse olla kiusaamisprosessissa mukana joko kiusaajaksi koettuna tai itsensä alaisensa kiusaamaksi kokevana osapuolena.

Johtajan keskeinen rooli työpaikan kiusaamistilanteissa tiedostetaan, mutta tutkimuksissa ei ole jäsennetty teoreettisesti vuorovaikutussuhteen näkökulmasta niitä kiusaamisprosesseja, joissa koettu kiusaaja on esimiesasemassa kiusattuun nähden.

Johtajan ja alaisen vuorovaikutussuhteiden tutkimus on muutenkin painottunut onnistuneen ja rakentavan johtajuuden myönteisten ja toivottujen vaikutusten, kuten alaisten sitoutumisen, motivoitumisen ja tuloksellisen työskentelyn tarkasteluun (Tepper 2000). Johtamisen tutkimus on myös ollut varsin normatiivista ja keskittynyt määrittelemään hyvän johtamisen periaatteita. Vasta vuosituhannen vaihteessa johtamistutkimuksen alalla on havahduttu siihen, että esimiehen ja alaisen vuorovaikutussuhteessa muodostuu myös monia kielteisiä ilmiöitä, joiden huomioiminen ja tarkastelu on aiheellista. Tiedeyhteisössä ja laajemmallakin yhteiskunnallisella tasolla on sittemmin käynnistynyt keskustelu esimerkiksi kielteisestä, huonosta ja epäammattimaisesta johtamisesta (esim. Eriksson 2006) sekä johtamisen eettisistä haasteista (esim. Huhtala, Puutio, Lämsä, Mauno, Kinnunen, Hyvönen \& Feldt 2010).

Pohdimme tässä katsauksessa, miten työpaikkakiusaamisen ilmiö kytkeytyy esimiehen ja alaisen, siis johtajan ja johdettavan väliseen ammatilliseen vuorovaikutussuhteeseen. Rajaamme tarkastelun edelleen asetelmaan, jossa kiusaajaksi koetaan esimies. Esittelemme myös haitallisen johtamisviestinnän käsitteen, jolla voidaan kuvata tähän asti vähemmän tarkasteltua johtajan ja johdettavan välistä epätarkoituksenmukaista vuorovaikutusta. Lopuksi tuomme esiin tapoja johtajan ja johdettavan vuorovaikutussuhteessa ilmenevien ongelmien tunnistamiseen ja käsittelyyn vuorovaikutusosaamisen ja sen kehittämisen näkökulmasta.

\section{TYÖPAIKKAKIUSAAMINEN ILMIÖNÄ}

Työpaikkakiusaaminen on niin yksittäistä työntekijää, tämän työtovereita kuin koko organisaatiota kuormittava pitkäkestoinen ja usein vaikeasti ratkaistava vuorovaikutusprosessi (ks. esim. Einarsen, Hoel,
Zapf \& Cooper 2003; Vartia 2001). Se on myös eettinen ja juridinen työsuojelutyön haaste.

Työpaikkakiusaamista on hahmotettu muun muassa kiusatuiksi itsensä kokevien kuvausten perusteella: Kiusaaminen on märitelty kiusattujen ominaisuuksiin ja/tai ammatilliseen toimintaan toistuvasti kohdistuvina ja heidän hyvinvointiaan, työtoverisuhteitaan sekä asemaansa uhkaavina kielteisinä ja loukkaavina toimenpiteinä (esim. Einarsen ym. 2003). Työpaikkakiusaamiseksi voidaan esimerkiksi kokea

- ammatillisen aseman uhkaaminen lesim. mielipiteen sivuuttaminen tai väheksyminen, syytökset osaamisen ja yrittämisen puutteesta, julkinen nolaaminen),

- koskemattomuuden uhkaaminen lesim. nimittely ja solvaaminen, pakottaminen ja uhkailu, yksilön piirteiden arvostelu),

- eristäminen lesim. työtä, työmahdollisuuksia tai työyhteisöä koskevan informaation salaaminen, työpaikan ryhmien ulkopuolelle sulkeminen),

- kuormittaminen lesim. ylimääräisten työpaineiden aiheuttaminen, tarpeettomat työn keskeyttämiset, epärealistiset työtehtävien aikataulutukset) ja

- ammatillisen aseman horjuttaminen ja työtehtäviä koskevat ei-toivotut muutokset lesim. myönteisen palautteen puute, tehdyistä virheistä muistuttaminen, vastuullisten tehtävien poistaminen ja vähempiarvoisten osoittaminen niiden tilalle). (Rayner \& Hoel 1997.)

Kiusaajaksi voidaan kokea johtaja siinä missä työtoveri tai alainenkin. Kiusaamisen ilmenemismuotoja tai vaikutuksia ei ole kuitenkaan systemaattisesti eritelty sen mukaan, missä asemassa koettu kiusaaja on kiusattuun nähden.

Johtajan ja alaisen vuorovaikutussuhteessa koettu työpaikkakiusaaminen voi saada suhteen valta-asetelmaan liittyviä ja työtovereiden vertaissuhteissa ilmenevästä kiusaamisesta poikkeavia tai niitä täydentäviä piirteitä, joita on mielestämme jatkossa syytä tarkastella tutkimuksissa lähemmin. Kiusaamisprosessin osapuolten välinen vallan epätasapaino on usein sisällytetty työpaikkakiusaamisen määritelmiin, mutta 
hierarkkisen valta-asetelman sijaan tällöin tarkoitetaan esimerkiksi toisen osapuolen heikompia mahdollisuuksia puolustautua tai vaikuttaa itseensä kohdistuvaan kielteiseen viestintään. Tämä voi korostua erityisesti silloin, kun koettu kiusaaja on esimiesasemassa, vaikkakin myös esimies voi kokea joutuneensa alaisensa kiusaamaksi (Savolainen \& Pörhölä, käsikirjoitus). Esimiehellä on silti alaisia enemmän mahdollisuuksia käyttää aseman-

sa tuomaa legitiimiä valtaa (myös väärin). Lisäksi hänellä on asemansa myötä mahdollisuus vaikuttaa viestinnällään haitallisesti laajemminkin henkilöstöön sekä organisaatioon, sen toimintaedellytyksiin ja resursseihin.

Viestinnälle on tyypillistä sen tilannesidonnaisuus ja tulkinnanvaraisuus. Myös kiusaamisen ilmenemismuodot voivat olla monitulkintaisia (Pörhölä, Karhunen \& Rainivaara 2006). Onkin vaikea osoittaa, milloin esimiehen oikeuksien ja niiden väärinkäytön raja lopulta ylittyy. Tutkijoiden keskuudessa on erilaisia näkemyksiä siitä, kuinka tahallista kiusaajan viestintä on. Yksi keskeinen syy tähän on, että koettujen kiusaajien näkemyksiä ja motiiveja ei toistaiseksi tunneta työpaikkakiusaamistutkimuksen tukeuduttua pääasiassa vain kiusatuksi itsensä kokevien tulkintoihin.

\section{VUOROVAIKUTUSSUHTEEN NÄKÖKULMA KIUSAAMISEEN}

Suomenkielisessä tutkimuskirjallisuudessa työpaikkakiusaamisen käsite kuvaa kiusaamista kaikenlaisissa työpaikan suhdeasetelmissa, eikä esimiehen ja alaisen suhteessa koettua kiusaamista ole käsitteellisesti erotettu työtovereiden vertaissuhteessa koetusta kiusaamisesta. Kansainvälisessä tutkimuskirjallisuudessa näitä erilaisia kiusaamissuhdeasetelmia on eri tieteenaloilla nimetty runsaslukuisemmin, joskaan määritelmät eivät merkittävästi eroa toisistaan, eivätkä ne erittele erilaisten kiusaamissuhteiden erityispiirteitä.

Johtajan ja johdettavan suhteessa ilmenevää, alai- seen kohdistuvaa esimiehen haitallista toimintaa on myös kuvattu kiusaamista laaja-alaisempana ilmiönä. Seuraavaksi määrittelemme vuorovaikutussuhteen näkökulman johtamisviestintään ja pohdimme kiusaamisen ilmenemistä johtajan ja johdettavan välisessä vuorovaikutussuhteessa.

Johtamisviestinnällä tarkoitamme johtajan vuorovaikutuskäyttäytymistä, joka ilmenee johtajan ja johdettavan vuorovaikutussuhteessa. Viestinnän näkökulman mukaan johtaminen perustuu johtajan ja johdettavan väliselle vuorovaikutussuhteelle (Fairhurst 2007; ks. myös Rouhiainen-Neunhäuserer 2009). Johtajuudessa on kyse johtajan ja johdettavan välisestä dyadissa, kahdenvälisessä suhteessa tapahtuvasta sosiaalisesta vaihdannasta. Johtajajohdettavasuhteen vaihdantateorian (LMX Theory) mukaan johtajan ja johdettavan kahdenväliset suhteet ovat luonteeltaan joko epämuodollisia tai muodollisia, ja suhteiden laatu riippuu siitä, miten epämuodollista ja läheistä on johtajan ja johdettavan tapa olla vuorovaikutuksessa toisensa kanssa. (Dansereau, Graen \& Haga 1975; Graen \& Uhl-Bien 1995.) Teoria korostaa sitä, että johtajalla ja johdettavalla molemmilla on vastuu vuorovaikutussuhteesta. Siten molempien osapuolten aktiivisuus voi parhaimmillaan johtaa läheiseen ja sitoutuneeseen suhteeseen, molemminpuoliseen luottamukseen sekä keskinäiseen kunnioittamiseen. Teorian mukaan johtajien tulisi myös pyrkiä laadukkaaseen vuorovaikutukseen johdettaviensa kanssa, sillä suhteen laatu vaikuttaa merkittävällä tavalla niin työntekijän työssä viihtymiseen kuin työn tuloksellisuuteen.

Mutta millainen on laadukas johtaja-johdettavasuhde? Johtamisviestintään kohdistuvat odotukset ja arvostukset ovat luonnostaan jännitteisiä ja usein myös jokseenkin idealistisia (Rouhiainen-Neunhäuserer 2009). Johtajilla ja heidän johdettavillaan voi myös olla hyvin erilainen kuva tavoitteellisesta ja sopivasta johtamistavasta. On myös arvioitava kriitti- 
sesti sitä, voiko johtajan ja johdettavan vuorovaikutussuhdetta edes kuvata lineaarisesti kehittyväksi ja syventyväksi, vai onko se pikemminkin alati muuttuva, dynaaminen prosessi, jossa on sekä muodollisen että epämuodollisen vuorovaikutussuhteen piirteitä ja jonka läheisyyden aste vaihtelee.

Johtajan ja johdettavan vuorovaikutussuhteessa piilee myös mahdollisuus kielteisiin vuorovaikutusilmiöihin. Työpaikkakiusaamisen tutkimuksissa kiusaajaksi ja kiusatuksi nimettyjen osapuolten piirteitä ja käyttäytymistä on kuvattu paljonkin, mutta heitä on silti käsitelty kiusaajan ja kiusatun rooleihinsa sidottuina ja erillisinä toimijoina, ei vuorovaikutussuhteen aktiivisina, toisiinsa vaikuttavina osapuolina. Viestinnän tutkimuksen alalla työpaikkakiusaamista on lähestytty interpersonaalisen viestinnän näkökulmasta, työtovereiden suhteessa ilmenevänä ja suhdetta muokkaavana prosessina (Pörhölä ym. 2006; Rainivaara 2009; Rainivaara \& Karhunen 2007; katso myös Sias 2009, 81). Tätä tarkastelutapaa voidaan soveltaa myös johtajan ja johdettavan välisessä vuorovaikutussuhteessa koettuun kiusaamiseen.

Työpaikkakiusaamisen ilmiö haastaa ihanteelliset kuvaukset toimivasta johtajan ja johdettavan suhteesta. Työelämän ongelmallisia vuorovaikutussuhteita ei kiusaamistilanteessa voi tarkastella tukeutuen olettamukseen, että vuorovaikutussuhteet muodostuvat ja jatkuvat aina ja vain, koska osapuolet haluavat olla suhteessa ja ponnistelevat kohti laadukkaampaa suhdetta. Tarkastelussa on huomioitava se, että johtajan ja alaisen vuorovaikutussuhde perustuu muodollisille työjärjestelyille. Esimies-alaissuhteiden ylläpitäminen on pakollista ja ei-vapaaehtoista, ja suhdetta on ylläpidettävä suhteen laadusta riippumatta. Tai ainakin vuorovaikutussuhdetta esimieheen on vaikea päättää tai siitä on vaikea "lähteä pois".

Useimmiten epätarkoituksenmukaiset, työtä häiritsevät ja haittaavat vuorovaikutustilanteet ja -suhteet johtajan ja johdettavan välillä on selitetty tutkimuskirjallisuudessa tehokkaan ja tarkoituksenmukaisen johtamisen puuttumisella. Ihmisten välisessä vuorovaikutuksessa ei ole kuitenkaan koskaan valtatyhjiötä ja johtamista ilmenee aina, mutta sen laatu vaihtelee. Muodollisessa esimies-alaissuhteessa koettavassa kiusaamisessa onkin johtamisen puuttumisen sijaan kyse ennemminkin haitallisesta johtamisviestinnästä. (Ks. Einarsen ym. 2007; Tepper 2007.)

\section{HAITALLINEN VIESTINTÄ VUOROVAIKUTUSSUHTEESSA}

Haitallisen johtamisviestinnän käsite pohjautuu Einarsenin, Aaslandin ja Skogstadin $(2007,208)$ käsitteeseen tuhoisa johtaminen (destructive leadership). Käytämme ilmiöstä käsitettä haitallinen johtamisviestintä. Tarkoitamme sillä joko tietoista tai tiedostamatonta johtajan vihamielistä ja epäeettistä viestintää sekä esimiesaseman tuoman legitiimin vallan väärinkäyttöä vuorovaikutussuhteessa alaisiin. Haitallinen johtaminen vahingoittaa organisaation etuja vaikeuttamalla ja/tai estämällä organisaation tavoitteiden toteutumista sekä heikentää alaisten työmotivaatiota, -hyvinvointia ja -tyytyväisyyttä (Einarsen ym. 2007).

Tepper (2007) ja Einarsen kollegoineen (2007) ovat koonneet eri tieteenalojen tutkijoiden tapoja määritellä johtamisen haitallisia ilmentymiä. Määritelmiä vertaamal-

\section{”VIESTINNÄLLE}

ON TYYPILLIST $\ddot{A}$

\section{SEN TILANNE-}

SIDONNAISUUS JA

\section{TULKINNAN-}

VARAISUUS." la hahmotimme

haitallisen johtamisviestinnän piirteitä. Ensinnäkin haitallista esimiestyötä on kuvattu alaiseen kohdistuvaksi vihamieliseksi verbaaliseksi ja nonverbaaliseksi viestinnäksi, joka heikentää alaisen työhyvinvointia ja -tyytyväisyyttä. Haitallisen johtamisviestinnän näkökulmasta tarkasteltuna kyseessä voi siis olla esimerkiksi johtajan epäasiallinen käyttäytyminen ja/tai verbaalinen aggressiivisuus, haukkuminen tai huutaminen. Kohdistuessaan toistuvasti tiettyyn alaiseen voidaan nämä vuorovaikutuksen muodot myös nähdä kiusaamisen ilmentyminä.

Toiseksi haitallinen johtamisviestintä voi liittyä vallan ja vastuun väärinkäyttöön, mikä myös kuvastaa ilmiön kohdentumista laajemminkin työyhteisöön. Asemansa myötä esimies voi hallita alaisiaan ja kontrolloida työympäristöä tavoilla, jotka luovat 
siihen pelon ja uhan ilmapiirin. Vallan ja vastuun väärinkäyttö voi ilmetä johtamisviestinnässä myös esimerkiksi alaisen työn kannalta tärkeän tiedon salaamisena tai alaisen sulkemisena päätöksentekokeskustelun ulkopuolelle. Vallan väärinkäyttöä on kuvattu myös pelolla johtamisen käsitteellä, joka usein liitetään perinteiseen autoritääriseen johtamiskäsitykseen, jossa kontrolli on merkittävä osa johtamista (Eriksson 2006). Pelolla johtamisen käsite saattaa ohjata ajattelua liian vahvasti pelontunteen alituiseen läsnäoloon johtajan ja johdettavan vuorovaikutussuhteessa tai johtamiskulttuurin yleiseen muutokseen. Pelon johtamisen tutkimuksissa on kuitenkin onnistuneesti havainnollistettu johtamisen voivan perustua myös vallan väärinkäytölle, kuten auktoriteettiaseman osoittamiselle, hierarkian korostamiselle, valvonnalle, liialliselle kontrollille, käskyttämiselle, tottelevaisuuskulttuurin vaalimiselle ja sanktioilla uhkaamiselle (ks. Eriksson 2006).

Kolmantena elementtinä korostuu haitallisen johtamisviestinnän epäeettisyys. Epäeettisyys voi liittyä laajemminkin johtajan epärehelliseen, mahdollisesti jopa laittomaan toimintaan, jossa esimies tavoittelee tavalla tai toisella johtamansa organisaation edun sijaan omaa etuaan. Mutta myös epälojaalius alaisia kohtaan voitaneen tulkita haitalliseksi johtamiseksi. Johtamisviestintää, joka perustuu petokseen ja valehteluun, alaisen uhkaamiseen tai pelotteluun ei voidakaan pitää eettisesti hyväksyttävänä tai sopivana.

Einarsen kollegoineen (2007) toteaa, että johtajan haitallinen toiminta yhdellä alueella ei väistämättä johda kielteiseen lopputulokseen myös toisella. Tämä vaikeuttaakin johtajan viestinnän arviointia ja kielteiseen toimintaan puuttumista. Johtajan autoritäärinen viestintä voi toki loukata alaisia, mutta samaan aikaan se voi tukea organisaation tavoitteiden saavuttamista. Kuten työpaikkakiusaamisenkin käsitteen kohdalla todettiin, eivät haitallista esimiestyötä kuvaavat määritelmätkään yksiselitteisesti kuvaa esimiehen toimintaa tahallisena. Johtajan haitallinen toiminta voi pikemminkin olla osoitus tämän taitamattomuudesta kuin tämän tarkoituksellisesta alaisten vahingoittamisesta (Einarsen ym. 2007).

Työpaikkakiusaamisen tavoin haitallinen johtamisviestintä ei myöskään aina ole ulkoasultaan epäasiallista, aggressiivista ja loukkaavaa viestintää, jota välttämällä johtaja varmistaisi, ettei alainen koe itseään kiusatuksi. Kiusaamiseksi voidaan yhtä lailla kokea esimerkiksi työtehtäviin kohdistuvat ei-toivotut toimenpiteet. Laajemmassa yhteiskunnallisessa keskustelussa kiusaaminen onkin voitu liittää uusiin, epämieluisiin työjärjestelyihin, kuten organisaatioiden uudelleenjärjestelyihin ja niistä aiheutuvaan irtisanomisuhkaan. Nykyiset johtamisen periaatteet painottavat liiketaloudellisten tavoitteiden ensisijaisuutta ja työntekijöissä pelkoa herättäviä muutoksia (Eriksson 2006). Haitallinen johtamisviestintä voikin muodostua työelämän ja -yhteisön muutoksen seurauksena.

Työelämän muutokset ja esimerkiksi tietoperustaisen työn uudenlainen luonne luovat johtamisviestintään jännitteitä ja ristiriitaisia odotuksia, joista nousee johtamisviestinnän haasteita (RouhiainenNeunhäuserer 2009). Muutokset eivät kuitenkaan vielä itsessään ole haitallista johtamisviestintää. Haitallinen johtamisviestintä ei selitä kaikkia alaisten kokemuksia kiusaamisesta, eikä johtaja ole vastuussa laajemmista työelämän muutoksista. Haitallisen johtamisviestinnän ilmentyminen kytkeytyy ennemminkin siihen, miten johtaja onnistuu hallitsemaan työelämän muutospaineita.

Työelämän muutospaineista ja niiden hallinnasta voidaan esimerkiksi mainita muutosjohtaminen. Muutosjohtamiseen liittyy aina tietyssä määrin kontrolli, mikä on paradoksaalista erityisesti nykyisissä tietoperustaisissa asiantuntijaorganisaatioissa. Asiantuntijaorganisaatioissa työn johtaminen vaatiikin erityistä johtamisviestinnän osaamista, koska esimerkiksi asiantuntija-alaiset edellyttävät osallistavaa johtamisviestintää ja työhön suhtaudutaan henkilökohtaisesti (Rouhiainen-Neunhäuserer 2009). Siten esimerkiksi johtajan antamaa palautetta työtehtävästä on vaikea erottaa henkilökohtaisen suoriutumisen arvioinnista. Ellei johtaja tietoisesti kiinnitä huomiota johtamisviestinnän erityispiirteisiin asiantuntijatyötä ohjatessaan, saattaa hän viestiä haitallisesti huomaamatta sitä itse.

Ajoittain voi kuitenkin olla vaikea osoittaa, milloin kyseessä on esimiehen legitiimi oikeus vaikuttaa alaisen työtehtäviin tai vaikkapa puuttua alaisen käyttäy- 
tymiseen tai työsuorituksiin, ja milloin taas ylittyy se raja, jolloin johtamisviestintää voidaan kuvata haitalliseksi, aseman tahalliseksi väärinkäytöksi ja alaisen kiusaamiseksi. Silti johtaja saattaa myös loukata ja kiusata alaistaan täysin tietoisesti ja tavoitteellisesti.

Esimiesasemaan liittyy neuvotteluvaraa myös arvoista eli siitä, millainen viestintä lopulta sallitaan tehokkaalle johtajalle tai millaista johtamista alaiset ovat valmiita sietämään osana työnkuvaansa. Saako johtaja olla johdettavilleen ilkeä, jos ilkeys kuitenkin johtaa tehokkuuteen ja tuloksellisuuteen? Miten suuret haitat sallitaan mahdollisten etujen ja hyötyjen saavuttamiseksi? Oikeuttaako päämäärä sittenkin mitkä tahansa keinot?

\section{HAITALLISEN JOHTAMISVIESTINNÄN KÄSITTELYYN TARVITAAN VUOROVAIKUTUSOSAAMISTA}

Yksiselitteisten johtamisviestinnän periaatteiden ja eettisen ohjeistuksen luominen on epäilemättä ongelmallista, mutta silti tarpeellista. Peräänkuulutamme organisaatioihin arvokeskustelua ja johtamisen eettisen ohjeiston tarkastamista. Tehtävään voidaan tarttua niin johtajien kuin koko henkilöstön vuorovaikutusosaamisen ja sen kehittämisen näkökulmasta.

Vuorovaikutusosaamisessa on kyse monimuotoisesta ilmiöstä, joka koostuu viestintään ja vuorovaikutukseen liittyvistä tiedoista, taidoista ja motivaatiosta viestiä ja olla vuorovaikutuksessa toisten kanssa (Spitzberg \& Cupach 2002). Johtamisessa tehokasta ja tarkoituksenmukaista viestintää määrittää siten se, mitä vuorovaikutussuhteen osapuolet tietävät

\section{"JohtAJAN VIESTINT $\ddot{A} \ddot{A}$ EI} SIIS VOIDA PIT $\ddot{A} \ddot{A}$ TAITAVANA, VAIKKA HÄN SAAVUTTAISIKIN TAVOITTEENSA, MUTTA VIESTINT ̈̈ EI OLE

\section{VUOROVAIKUTUSTILANTEESSA} TARKOITUKSENMUKAISTA." den että tarkoituksenmukaisuuden kriteerit (Spitzberg \& Cupach 2002). Kompetentti, taitava viestintä on sekä tehokasta ja tavoitteellista että tarkoituksenmukaista ja sopivaa. Johtajan viestintää ei siis voida pitää taitavana, vaikka hän saavuttaisikin tavoitteensa, mutta viestintä ei ole vuorovaikutustilanteessa tarkoituksenmukaista. Konteksti määrittää sen, millainen johtamisviestintä on tarkoituksenmukaista. Osaaminen edellyttää vuorovaikutuskäyttäytymisen mukauttamista ympäröivään kulttuuriin, aikaan, vuorovaikutussuhteeseen, -tilanteeseen ja paikkaan sekä vuorovaikutuksen funktioon. Taitava johtaja siis tunnustaa ja huomioi oman viestintätavoitteensa lisäksi vuorovaikutussuhteen toisen osapuolen, hänen tarpeensa ja tavoitteensa sekä kontekstin eri ulottuvuudet. (Rouhiainen-Neunhäuserer 2009.)

Kuten olemme todenneet, voi haitallista johtamisviestintää olla vaikea tunnistaa, koska siihen liittyy tulkinnanvaraisuutta. Siten myös siihen puuttuminen on haasteellista. Mielestämme työelämässä keskeiseen vuorovaikutusosaamiseen kuitenkin liittyy tieto ja ymmärrys ristiriitatilanteista sekä taidot ja motivaatio niiden puheeksi ottamiseen, käsittelyyn, sovitteluun sekä seurantaan.

Työpaikkakiusaamiseen puuttumiseen ja käsittelyyn liittyvät toimintaohjeet eivät nykyisellään sovellu haitallisen johtamisviestinnän käsittelyyn, sillä ne on usein kohdennettu työtoverinsa kiusaamaksi tulleelle työntekijälle tai esimiehille tilanteissa, joissa kiusaamista koetaan alaisten keskinäisissä suhteissa. Koetun kiusaajan ollessa hierarkkisesti vahvemmassa asemassa voikin kiusatuksi itsensä kokevan asema olla erityisen heikko. Miten siis toimia tilanteessa, joissa kiusaajaksi koetaan sama henkilö, jonka vastuulla olisi kiusaamisen ennaltaehkäisy, siihen puuttuminen ja sen käsittely?

Jatkossa olisi tarpeen kehittää vaihtoehtoisia toimintamalleja, joiden avulla alaiset voisivat ennen 
tilanteen laajentumista ja oman terveytensä murtumista tuoda esiin kokemansa haitallisen johtamisviestinnän ja kiusaamisen. Tarvitaan myös johtajille ja koko henkilöstölle suunnattua viestintäkoulutusta siitä, miten käsitellä johtajan ja johdettavan vuorovaikutussuhteen ongelmia. Keskeinen kysymys on sekin, miten johtaja voi ottaa vastaan mahdolliset itseensä kohdistuvat kiusaamissyytökset.

Koska haitallinen johtamisviestintä todentuu vuorovaikutussuhteessa, on siihen puututtava relationaalisesti, vuorovaikutussuhteeseen keskittyen. Johtaja on työpaikan erilaisissa ristiriitatilanteissa aina avainasemassa, mutta vastuu viestinnästä ei koskaan ole yksin hänen. Viestinnän tietoja, taitoja ja motivaatiota edellytetään johtajien tavoin myös johdettavilta. Keskustelemalla johtamisviestinnän periaatteista organisaatiossa niin johtajien kuin johdettavien kanssa ja muuttamalla periaatteita voidaan vaikuttaa myös laajemmin organisaation vuorovaikutuskäytäntöihin. Organisaatio muodostuu lukuisista vuorovaikutussuhteista - vuorovaikutussuhteet muodostavat organisaation. Johtajien ja johdettavien vuorovaikutussuhteisiin ja vastuulliseen johtamisviestintään paneutumalla luodaan organisaatiotason käytäntöjä ja tapoja viestiä ja olla vuorovaikutuksessa toisten kanssa ammattimaisesti, myös muutos- ja ristiriitatilanteissa.

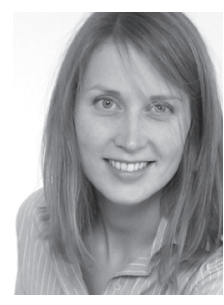

FT Maijastiina RouhiainenNeunhäuserer työskentelee viestintäkonsulttina Berliinissä. Hän on väitellyt vuonna 2009 Jyväskylän yliopistossa puheviestinnän oppiaineessa johtajan vuorovaikutusosaamisesta ja sen kehittymisestä tietoperustaisessa organisaatiossa.

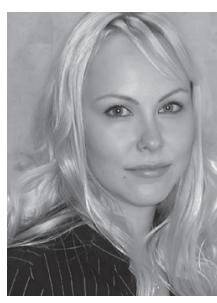

FM Sini Tuikka lo.s Rainivaaral työskentelee julkaisuamanuenssina Jyväskylän yliopiston kirjaston julkaisuyksikössä ja valmistelee puheviestinnän oppiaineessa väitöskirjatutkimusta työpaikan kiusaamissuhteiden kehittymisestä.

Kiitämme Aikuiskasvatus-lehden toimituskuntaa sekä yliopistonlehtori, FT Marko Siitosta Jyväskylän yliopistosta ja yliopistonlehtori, FM Sanna Karhusta Helsingin yliopistosta käsikirjoituksemme kommentoimisesta.

\section{KIRJALLISUUS}

Bennis, W. G. \& Nanus, B. (1985). Leaders: The strategies for taking charge. New York: Harper \& Row.

Dansereau, F., Graen, G. G. \& Haga, W. (1975). A vertical dyad linkage approach to leadership in formal organizations. Organizational Behavior and Human Performance 13, 46-78.

Einarsen, S., Aasland, M. S. \& Skogstad, A. (2007). Destructive leadership behavior: A definition and conceptual model. The Leadership Quarterly 18, 207-216.
Einarsen, S., Hoel, H., Zapf, D. \& Cooper, C. L. (2003). The concept of bullying at work. The European tradition. Teoksessa S. Einarsen, H. Hoel, D. Zapf \& C. L. Cooper (toim.) Bullying and emotional abuse in the workplace: International perspectives in research and practice. London: Taylor \& Francis, 3-30.

Eriksson, M. (2006). Pelko, johtaminen ja asiantuntijatyö. Teoksessa Parviainen, J. (toim.) Kollektiivinen asiantuntijuus. Tampereen yliopistopaino, 115-151.

Fairhurst, G. T. (2007). Discursive leadership. In conversation with leadership psychology. Thousand Oaks: SAGE. 
Graen, G. B. \& Uhl-Bien, M. (1995). Relation-based approach to leadership. Development of leadermember exchange (LMX) theory of leadership over 25 years: Applying a multi-level, multi-domain perspective. Leadership Quarterly 6, 219-247.

Huhtala, M, Puutio, R., Lämsä, A.-M., Mauno, S., Kinnunen, U., Hyvönen, K. \& Feldt, T. (2010). Eettisesti haastavat tilanteet ja niiden kuormittavuus johtajien työssä: fokusryhmäkeskusteluiden analyysi. Työelämän tutkimus 1/2010. Tampere: Työelämän tutkimusyhdistys ry.

Lehto, A.-M. \& Sutela, H. (2008). Työolojen kolme vuosikymmentä. Työolotutkimusten tuloksia 19772008. Helsinki: Tilastokeskus.

Pörhölä, M., Karhunen, S. \& Rainivaara, S. (2006). Bullying at school and in the workplace. A challenge for communication research. Teoksessa C. Beck (toim.) Communication Yearbook 30. Mahwah, NJ: Lawrence Erlbaum, 249-301.

Rainivaara, S. (2009). Workplace bullying relationships. Teoksessa T. A. Kinney \& M. Pörhölä (toim.) Anti and pro-social communication. Theories, methods, and applications. New York: Peter Lang, 59-70.

Rainivaara, S. \& Karhunen, S. (2007). Näkökulmia koulun ja työpaikan kiusaamissuhteisiin. Teoksessa T.-R. Välikoski, E. Kostiainen, E. Kyllönen \& L. Mikkola (toim.) Prologi. Puheviestinnän vuosikirja 2006. Jyväskylä: Prologos ry, 8-40.

Rayner, C. \& Hoel, H. (1997). A summary review of literature relating to workplace bullying. Journal of Community and Applied Social Psychology 7, 181-191.
Rouhiainen-Neunhäuserer, M. (2009). Johtajan vuorovaikutusosaaminen ja sen kehittyminen. Johtamisen viestintähaasteet tietoperustaisessa organisaatiossa. Studies in Humanities 128, Jyväskylän yliopisto.

Savolainen, A. \& Pörhölä, M. Käsikirjoitus. Managers as targets of workplace bullying.

Sias, P. M. (2009). Organizing relationships. Traditional and emerging perspectives on workplace relationships. Thousand Oaks, CA: SAGE.

Spitzberg, B. H. \& Cupach, W. R. (2002). Interpersonal skills. Teoksessa M. L. Knapp \& J. A. Daly (toim.) Handbook of interpersonal communication 13. painos). Thousand Oaks: SAGE, 564-611.

Tepper, B. J. (2000). Consequences of abusive supervision. Academy of Management Journal, 178-190.

Tepper, B. J. (2007). Abusive supervision in work organizations: Review, synthesis, and research agenda. Journal of Management 33, 261-289.

Työturvallisuuslaki 738/2002.

Vartia, M. (2001). Consequences of workplace bullying with respect to the well-being of its targets and the observers of bullying. Scandinavian Journal of Work Environment Health 27, 63-69. 